The Middle East Studies Association of North America, Inc. (MESA) was organized in 1966 by a group of American and Canadian scholars on the Middle East to

- promote high standards of scholarship and instruction in this area;

- facilitate communication among scholars through meetings and publications; and

- foster cooperation among persons and organizations concerned with the scholarly study of the Middle East.

MESA focuses on the study of the Middle East since the rise of Islam, principally from the viewpoint of the humanities and the social sciences. Its membership is international.

Persons of scholarly training and/or achievement in Middle East studies are eligible to become Full Members $(\$ 50$, Retired $\$ 25$, Joint $\$ 60$ ). Other categories of membership are Associate (\$50), Student (\$25), and Institutional (\$500). Each membership is on a calender-year basis. Membership includes subscriptions to the International Journal of Middle East Studies, the MESA Bulletin, and the MESA Newsletter. Application forms may be obtained from the MESA Secretariat, Department of Oriental Studies, University of Arizona, Tucson, Arizona 85721, (602) 621-5850.

MESA is a nonprofit corporation with tax-exempt status. Contributions to the Association are deductible under both U.S. Federal and British income tax regulations.

Honorary Fellows: Aziz Atiya, Claude Cahen, Majid Khadduri, Albert Hourani, William Montgomery WatT

Past President: Elizabeth Fernea

President: Michael C. Hudson

President-Elect: William B. QuandT

Directors: 1985-1987: David A. King, Amal Rassam

1986-1988: William Cleveland, Farhad Kazemi

1987-1989: FedWa Malti-Douglas, John O. Volt

Executive Secretary \& Treasurer: MICHAEL E. BONINE

The following publications are available from the MESA Secretariat (please write for a price list):

- American Images of Middle East Peoples: Impact of the High School, by Michael W. Suleiman. MESA 1977.

- Directory of Graduate and Undergraduate Programs and Courses in Middle East Studies in the United States, Canada, and Abroad. MESA, published biennially.

- The Image of the Middle East in Secondary School Textbooks, by William J. Griswold. MESA 1975.

- Abstracts of Papers Delivered at the Annual Meeting of the Middle East Studies Association (1977-1980 only).

- Back issues of the MESA Bulletin. 


\section{Bibliotheca Islamica}

BOX 14474 UNIVERSITY STATION MINNEAPOLIS, MN 55414/U.S.A.

\section{New:}

Origins and Development of the Turkish Novel by Ahmet Ö. Evin

The First Modern Arab State: Syria under Faysal, 1918-1920

by Malcom B. Russell

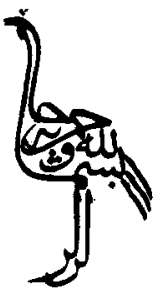

Paper $\$ 14.95$

Ciloth $\$ 28$

Major Themes of the Qur'an by Fazlur Rahman

Cloth $\$ 25$ /Paper $\$ 14.95$

Lawyers and Politics in the Arab World, 1880-1960 by Donald M. Reid

C.loth $\$ 40$

The Roots of Modern Egypt. A Study of the Regimes of 'Ali Bey al-Kabir and Muhammad Bey Abu al-Dhahab, 1760-1775, by Daniel Crecelius

Ciloth $\$ 28$

Mirrors. A Novel by Nagib Mahfuz. Translated by Roger Allen Cloth $\$ 20 /$ Paper $\$ 11.95$

The Judicial Administration of Ottoman Egypt in the Seventeenth Century by Galal H. El-Nahal

Cloth $\$ 18$

The School Principal by Jalal Al-e Ahmad

Paper $\$ 11.95$

An Introduction to Ottoman Poetry by Walter G. Andrews, Jr.

Paper $\$ 14.95$

Modern Turkish Drama by Talat Sait Halman

Paper $\$ 19.95$

God's World by Nagib Mahfuz

Paper $\$ 11.95$

The History of Mehmed the Conqueror by Tursun Beg.

Paper $\$ 19.95$

The Political and Social History of Khurasan under Abbasid Rule, 747-820, by Elton L. Daniel

Cloth $\$ 28$

Contemporary Turkish Short Stories. An Intermediate Reader by

Richard L. Chambers and Gunay Kut (Alpay)

Ciloth $\$ 14$

An Anthology of Modern Turkish Short Stories edited by Fahir Iz

Paper $\$ 11.95$

In the Eye of the Beholder. Tales of Egyptian Life from the Writings

of Yusuf Idirs edited by Roger Allen

Cloth $\$ 20$ / Paper $\$ 11.95$

The Aqquyunlu. Clan, Confederation, kmpire by John. E. Woods

Cloth $\$ 28$

The Odyssey of Farah Antun. A Syrian Christian's Quest for

Secularism by Donald M. Reid

Ciloth $\$ 25$

The Shuster Mission and the Persian Constitutional Revolution by Robert A. McDaniel

Cloth $\$ 25$

Unity in the Ghazals of Hafez by Michael C. Hillmann

Cloth $\$ 25$

The Divan of Manuchihri Damghani. A Critical Study

by Jerome W. Clinton

Paper $\$ 9.95$

Ibn al-Haytham's Optics. A Study of the Origins of the Scientific Method by Saleh Beshara Omar

Modern Egyptian Drama. An Anthology by Farouk Abdel Wahab

Cloth $\$ 20$

Cloth $\$ 25$ 